\title{
Editorial Review Essay
}

\author{
Gillian Sullivan Mort and Amanda Roan
}

\section{Introduction}

This themed issue of the Queensland Review, 'Queensland: The Smart State', provides a focus on both the Smart State policy initiatives and related research on important aspects of the evolving knowledge economy in Queensland. The engagement of Queensland with the global knowledge economy is a vital issue for the state and its people. We have taken this opportunity to present an analysis of aspects of the Queensland Government policy, to provide reflections on broad aspects of the knowledge economy developing in Queensland and to open a dialogue between government and academia in this important area. The themed issue is one result of a research collaboration by the Special Editors Gillian Sullivan Mort and Amanda Roan of the UQ Business School, University of Queensland in the areas of innovation, knowledge economy, country/regional image and the policy initiatives required to sustain and enhance a country's or region's position in the global knowledge economy.

Queensland's 'Smart State' suite of policies is an example of a government initiative aimed at developing a regional entity that will prosper by meeting the challenges of technological change and a turbulent global environment. It consists of a mixture of policies of economic development, education and training, fostering innovation and building strong communities towards engagement in the global knowledge economy. However, although there is a burgeoning literature on innovation and entrepreneurship there have been relatively few attempts to gain a deeper appreciation of the impact of such policies on business, communities and individuals. Although concepts such as 'knowledge' and 'innovation' and industries such as 'information and communication technology (ICT)' and 'biotechnology' are easily associated with current interpretations of economic prosperity, little research has been available on how these policies are shaping Queensland's economic and social landscape. Evaluation of such policies is generally undertaken through measuring the growth of industries, jobs growth, revenue, profits and exports or measurement of the impact of policy on various stakeholders. This issue of the Queensland Review intends to go beyond surface evaluation. It aims to unpack the meanings and manifestations of Queensland the 'Smart State'. Papers were invited from a 
variety of perspectives and disciplines in areas including but not limited to emerging industries, government policy, the knowledge economy and traditional and creative industries.

\section{Papers in the themed issue}

A variety of papers were selected for the themed issue after double blind peer review. A first group can be identified as reflecting on policy matters in the 'Smart State' and seeking to analyze the basis of the policy framework being developed in Queensland, including a focus on skills development and entrepreneurial orientation. A second group of papers provide a broader approach to various knowledge economy or knowledge society issues such as intellectual property, innovation in firms, ebusiness and community. A third group of papers reflect on other Queensland issues which provide a broader context for a 'smart state', such as preferential voting in a liberal democracy and the Pilbeam mayoralty in Rockhampton.

Firstly, Ken Wiltshire provides a paper, 'Queensland - Smart State, Positioning Queensland: An International Perspective', that locates Queensland within the international policy context. Wiltshire highlights how an array of international actors, including UNESCO and the United Nations, have broadened concepts such as the 'knowledge economy' and 'information economy' to 'knowledge society' and 'information society' thus implying the necessity to include social and political institutions. Wiltshire's article provides international benchmarks and policy frameworks through which we can start to assess policy regimes such as the 'Smart State' initiatives. In particular, Wiltshire's article provides an outline of the OECD's 'learning region' principles. The learning region mediates the traditional reliance on natural, physical and human capital towards generating the exchange and application of knowledge. Innovation is the key in this new competitive environment. Wiltshire notes the emphasis on technology is very welcome by large firms and research institutions, but can breed a perception of neglect of the state's traditional industries, small business and basic policy ingredients such as education. He calls for an avoidance of 'quick fix rhetorical solutions' such as simply installing computers in schools. In contrast, his article provides some detail of reforms necessary to Queensland's education and training system and promotes a mindset change that stresses the importance of intercultural understanding and multi-lateral linkages. An invitation to the World Summit on the Information Society will be a start.

Government policy in the area of the knowledge economy, or the 'smart state', might rightly be considered 'a work in progress', not least because, as Gillian Sullivan Mort and Amanda Roan point out in their paper 'Smart State: Queensland in the Knowledge Economy', understanding of the elements of the knowledge economy itself, and policy frameworks to foster this type of economic development, are in themselves emergent. Sullivan Mort and Roan's paper provides a discussion of aspects of the knowledge economy, identifies the research in this area of economic development and policy formulation likely to be of use in understanding the Queensland Smart State initiatives, and then provides an 
introductory analysis of the policy framework now being established in Queensland. Sullivan Mort and Roan conclude that there are in place in Queensland many of the policy elements required to foster development towards an engagement in the global knowledge economy. However, they highlight that the policy framework still needs much greater clarity and focus and would benefit from the formulation of more consistent goals and a long-term horizon for implementation.

The article by Stuart Cunningham, Greg Hearn and Jeff Jones, 'Smart State is also Creative State: Opportunities for Queensland in the Creative Industries' challenges what they identify as a bias in Queensland policy towards science and technology. These authors argue that Queensland can no longer afford to understand the social and creative disciplines as commercially irrelevant, 'civilising' disciplines but rather that these disciplines must be recognised as the vanguard of economic growth. Cunningham et al's article is not simply lobbying for creative industries; rather, it examines shortcomings within knowledge-related public policy, which simply focus on science, technology and engineering. The authors identify two counterproductive social phenomena that arise from these biases. First, the failure to develop the social infrastructure required to develop and commercialise new technology and second, the ignoring of knowledge systems that reside in everyday human/social organisations. This paper argues that there is an urgent need for policy makers to gain a greater understanding of knowledge consumption service industries such as education, entertainment, financial services, media and communication and the crucial role creative industries play in the new economy. The authors provide examples of two areas - interactive design and changes in the broadcast industry - that they argue current policy frameworks and approaches to Research and Development (R \& D) do not adequately address. Cunningham et al's paper challenges the reader not only to reframe attitudes towards new knowledge industries but also to reassess economic systems, organisational forms and policy directions.

Building an entrepreneurial environment and fostering entrepreneurship are important goals for any state moving towards a knowledge economy which requires not only knowledge and training in technical fields but also the orientation towards and skills to undertake entrepreneurial ventures. Jessica Kennedy, Judy Drennan, Patty Renfrow and Bernadette Watson in their paper 'The Influence of Role Models on Students' Entrepreneurial Intentions' contribute towards an understanding of how an entrepreneurial mindset, an important enabling aspect for the growth of a knowledge economy, might be developed in the 'Smart State'. They report on a study of the influence of role models on university students' entrepreneurial intentions and choice of academic discipline. They find that students with higher intentions to start their own business were more likely to be enrolled in a dual degree with the business discipline. Family members are the most frequently reported role models for both choice of discipline and entrepreneurial intention. However, with regard to entrepreneurial intention itself, the next most important role models are peers and famous people suggesting the ability to influence, as part of a policy direction, the types of role models students are exposed to before and 
after entry to university. They also call for educational programs to address the substantial under-representation of women in entrepreneurship.

In 'Singapore: Reflections and Implications of Another Smart State' Clive Edwards draws on his in-depth knowledge of the Singapore economy to provide an analysis of how industrial economic frameworks can be developed into coherent economic policy. His analysis suggests that before the concept of a knowledge economy became popular, Singapore was pursuing many policies that engaged the island economy with the global economy, developed the skills of its people, vastly improved living conditions and maintained a forward looking innovative direction. He reflects on the implications for other regions, such as Queensland, and on whether Singapore's unique political environment means that the development and implementation of their economic model can be copied elsewhere.

Within any environment of innovation and creativity the importance of intellectual property (IP) cannot be overstressed. Paul Steffens, Michael Waterhouse, Art Shulman and Andrew Wollin begin the second group of papers with 'An Audit Tool for Intellectual Property Management: IP Management in the Queensland Department of Primary Industries'. They provide an article that emphasizes the centrality of intellectual resources to the knowledge-based economy. This paper showcases the Queensland Department of Primary Industries (QDPI) and its role in research and development $(\mathrm{R} \& \mathrm{D})$ and extension services. The IP management framework in this paper draws on many of the themes of the Smart State and associated literature: the generation of new ideas; protecting IP rights; ensuring the uptake of new ideas; and providing the corporate support to ensure effective leadership and management of innovation. In this paper we see recognition of the pivotal role played by pubic sector agencies in knowledge creation. The audit tool developed by these authors has potential to be used beyond the public sector, but here it highlights the work of a public sector agency that has a long history within this state of being 'smart'.

Jay Weerawardena's paper 'Innovation in Queensland Firms: Implications for the Smart State' reports on a large study of manufacturing firms in Queensland. The study examines the role of learning capabilities in innovation and competitive advantage in the context of the Queensland firms and finds that both technological and non-technological innovations lead to competitive advantage. The findings contribute to the theory of competitive advantage and firm level antecedents of innovation. The paper provides a firm level insight into how innovation, through learning and knowledge development, can be enacted. The paper concludes with implications for the Smart State.

Kim Bryceson in the paper 'EBusiness Impacts on the Peanut Industry in Queensland: A Case Study' provides an interesting analysis of the impact on a traditional industry, the peanut industry, of the 'smart' innovation of eBusiness. She concludes that the use of internet-enabled business practices between members of the industry chain is increasing rapidly for a variety of reasons. Such business practices are increasing first, because of growing respect for eBusiness as a means of improving efficiencies and productivity. The second reason for adoption relates to pressures to adopt the innovation or be substituted as a supplier. The third reason 
for adoption is because of the improved information/knowledge management provided in the eBusiness format for quality assurance, food safety, real time information, decision support and product tracking. The paper provides a very useful perspective on how knowledge, in the broad definition, can infuse traditional industries that are far removed from the industries, such as biotech, more immediately associated with 'smartness'.

Jane Summers and Meredith Lawley in the paper 'Can Regional Communities Successfully Participate in the Smart State? The Case of Maranoa On-line Regional Community Portal' provide an evaluation of the implementation of a regional community portal in Maranoa. Portals are, they explain, web sites offering a variety of internet services from a single location, with community portals having a distinct focus which brings together people with a common set of needs or interests. The Maranoa portal was developed as both a tool to encourage local business to move on-line and develop e-commerce facilities and also with the dual role as a community development initiative. Summers and Lawley conclude that, while the initial sign on and awareness stage appears to have been successful in encouraging some level of participation in the 'Smart State', especially for business, in effect the Maranoa portal did not articulate well with any wider understanding of innovation or a knowledge economy framework. As Summers and Lawley point out, this research highlights the need for strong knowledge development to accompany such initiatives beyond the provision of appropriate infrastructure and access.

Neil Paulsen's article 'Managing Strategic Challenges in Community Sector Organisations' treats community issues from a different perspective. The paper deals with the non-profit (third) sector often ignored in discussion of public policy, innovation and economic development. However, as Wiltshire emphasized in his paper, this sector is important for the development of the broader 'knowledge society'. Given the realignment in the relationships among the not-for-profit, forprofit and government sectors, the recognition of the need for innovation in the notfor-profit sector and the need to incorporate social policy dimensions in the development of the knowledge economy in Australia, Paulsen's paper is timely. Paulsen outlines the themes in the research literature regarding the operation of community and non-profit organizations in the current environment. Through a focus group of community sector managers he identifies the key issues facing these managers in Queensland including funding, governance and the management of volunteers. However, he highlights the uncertainty created by policy trends towards amalgamation, collaboration and partnership and the challenges these present in the development of the 'Smart State'.

The final two papers provide a broader context for the knowledge economy in Queensland. In a liberal democracy, policy directions are brought about by the election of governments and their policy platforms. The article by Stephen Stockwell 'The Impact of Optional Preferential Voting on the 2001 Queensland State Election' deals with the fundamental question of the electoral process's ability to deliver the will of the majority through the democratic process in Queensland. It questions the use of optional preferential voting during the 2001 Queensland state election asking the question: is optional preferential voting good for democracy? 
Doug Tucker in 'Transforming a Provincial City: The Pilbeam Mayoralty in Rockhampton 1952-1982' provides an account of the Mayoralty of Rex Pilbeam in Rockhampton from 1952-1982. This article illustrates how one man's determination and superior public management ability could provide economic and community infrastructure which allowed this provincial town to become one of Queensland's most important regional centres. Although this article details an administration that existed long before the emergence of knowledge and innovation policies, Rex Pilbeam's administration demonstrated many hallmarks of such policies that jurisdictions now seek to emulate.

\section{Finally}

This themed issue has presented a broad perspective on the salient issues in developing Queensland as the 'Smart State'. This is, however, an important area for continued research and policy development and dialogue between Queensland Government and Queensland academics. It is anticipated that this themed issue of the Queensland Review will prompt analysis and reflection, contribute to both improved public policy and a wider dialogue between Queensland Government and Queensland academics, as well as broader discussion concerning the development of Queensland as a 'smart state'.

The papers in this collection are a result of the enthusiastic response of the authors to the opportunity to contribute to the special theme and share their research with a wider audience, and the timely and insightful critiques of the reviewers. As special editors we wish to thank the contributors and reviewers. We also wish to thank, in particular, Dr George Lafferty, formerly of the UQ Business School and joint Editor of the Queensland Review, for the opportunity to present this themed issue.

The cover image shows the structure of the protein, Photosystem II, determined by electron crystallography ${ }^{1}$. The development of a clean, sustainable and economically viable energy supply for the future is one of the most urgent challenges of our generation. At the Institute of Molecular Bioscience (IMB, UQ) high resolution structural biology and biotechnology is being combined to develop strains of green algae that can produce hydrogen fuel $\left(\mathrm{H}_{2}\right)$ from solar energy and water $\left(\mathrm{H}_{2} \mathrm{O}\right)$. Photosystem II drives the first stage of the $\mathrm{H}_{2}$ production process by capturing solar energy and using it to split water into protons $\left(\mathrm{H}^{+}\right)$, electrons $\left(\mathrm{e}^{-}\right)$and molecular oxygen $\left(\mathrm{O}_{2}\right)$. The algae then recombine the $\mathrm{H}^{+}$and $\mathrm{e}^{-}$to produce $\mathrm{H}_{2}$ gas. Combustion of $\mathrm{H}_{2}$ yields only water, eliminating net water use and the production of harmful greenhouse gases, associated with the burning of fossil fuels. This research is a striking example of innovation at work in the 'Smart State'.

\section{Gillian Sullivan Mort}

Amanda Roan

UQ Business School

University of Queensland 


\section{EDITORIAL REVIEW ESSAY}

\section{Note}

1 Adapted by Ben Hankamer from the Journal of Structural Biology 135, $262-9$ (2001). Reproduced by permission of Ben Hankamer. 